\title{
FLORISTIC COMPOSITION OF THE INTERFACE OF A SEASONAL SEMIDECIDUOUS FOREST WITH A PASTURE
}

\author{
Marcele Almeida da Silva ${ }^{1}$, Mariane Martins Rodrigues ${ }^{1}$, Ciro Abbud Righi ${ }^{1}$
}

${ }^{1}$ Escola Superior de Agricultura “Luiz de Queiroz" - ESALQ/USP. E-mail: as_marcele@yahoo.com.br; mariane.rodrigues@hotmail.com.br; ciro@usp.br

\section{ABSTRACT}

In this study, the floristic composition of the interface of the seasonal semideciduous forest inserted in a pasture matrix was evaluated. Three transects of $10 \mathrm{~m}$ wide by $50 \mathrm{~m}$ long from the edge to the center of the fragment were installed systematically. Few species were responsible for more than half of the individuals, contributing to the low species richness detected. Bauhinia forficata and Urera baccifera have represented almost $40 \%$ of the individuals sampled. Besides this, a high density of pioneer species and abundance of few species up to $50 \mathrm{~m}$ were verified, confirming that the edge effect extends beyond the sampled distance.

Keywords: Edge effect, structure, species richness, Bauhinia forficata, Urera baccifera

\section{COMPOSIÇÃO FLORÍSTICA DA INTERFACE DE UMA FLORESTA ESTACIONAL SEMIDECÍDUA COM UMA PASTAGEM}

\section{RESUMO}

Nesse estudo foi avaliada a composição florística da interface da floresta estacional semidecídua inserida em uma matriz de pastagem. Foram instalados de modo sistemático três transectos radiais de $10 \mathrm{~m}$ de largura por $50 \mathrm{~m}$ de comprimento a partir da borda até o centro do fragmento. Poucas espécies foram responsáveis por mais da metade dos indivíduos, contribuindo para a baixa riqueza de espécies. Bauhinia forficata e Urera baccifera representaram quase $40 \%$ dos indivíduos amostrados. Além disso, verificou-se alta densidade de espécies pioneiras e abundância de poucas espécies até os $50 \mathrm{~m}$, confirmando que o efeito de borda se estende para além da distância amostrada.

Palavras-chave: Efeito de borda, estrutura, riqueza de espécies, Bauhinia forficata, Urera baccifera 


\section{INTRODUCTION}

The Atlantic Forest was traditionally the source of products both agricultural and forestry ones. Despite its relevance, the biome still suffers severely with the pressure of the opening of new areas for crops as well as for disarranged human occupation (DEAN, 1995). The Atlantic Forest used to be one of the biggest tropical forests in the world, being well known its importance for the preservation of species diversity. It covered an area of 1,3 million $\mathrm{km}^{2}$, nowadays only about $11,7 \%$ of the former area exists, being restricted to scattered fragments (RIBEIRO et al., 2009).

According to the most recent mapping achieved by Information System of São Paulo State SIFESP (2010), the Atlantic Forest which previously covered nearly 80\% of São Paulo state, was reduced to only about $17,5 \%$. At least $12 \%$ of the state forests, about 530 thousand hectares are fragmented in small clusters, frequently with an area below 10 hectares, being most of these fragments found in advanced state of degradation due to an existing intense anthropic interference, as agriculture, pastures and industrial activities (ZORZETTO, 2010).

The fragmentation causes a decrease of both animal flow and pollen and seeds dispersion, compromising the local species perpetuation, as well as the environmental services provided (VIANA, 1995). The forest cuts in small plots distant from each other causes microclimatic changes in the edges, inducing effects such as higher incidence of solar radiation, less soil humidity, higher wind exposure (LIMA-RIBEIRO, 2008; NASCIMENTO \& LAURANCE, 2006) and an increase in plant density. Normally, the older the edge, the higher the difference found in the species composition (RODRIGUES, 1998).

According to the Atlas of the Municipalities of the Atlantic Forest disclosed in 2014, the municipality of Piracicaba-SP has only $4,5 \%$ of its native forest cover, being only the area under the law of the Atlantic Forest considered - Law 11.428/06 (INSTITUTO FLORESTAL, 2005). According to the same document, the forest fragments which belong to the landscape are typically small, isolated and highly disturbed, distributed around 600 fragments, being that the smallest one (until 10 ha) represent $75,5 \%$ of the total. Thus, it is important to check the effect of the surroundings over the forest remnants in areas, which have been a long time anthropized in this region. In this work, the goal was to evaluate the floristic composition of the interface of a seasonal semideciduos forest as an answer to the edge effects and the surrounding with pasture. 


\section{MATERIALS AND METHODS}

The study was conducted in a forest fragment called "Mata da Pedreira", situated in the Campus of "Luiz de Queiroz" College of Agriculture, of University of Sao Paulo, ESALQ-USP, in Piracicaba, State of São Paulo, Brazil (2242’40'’S e 47³7’30” O) (Figure 1) with an average height of 546 m (SENTELHAS, 1998).

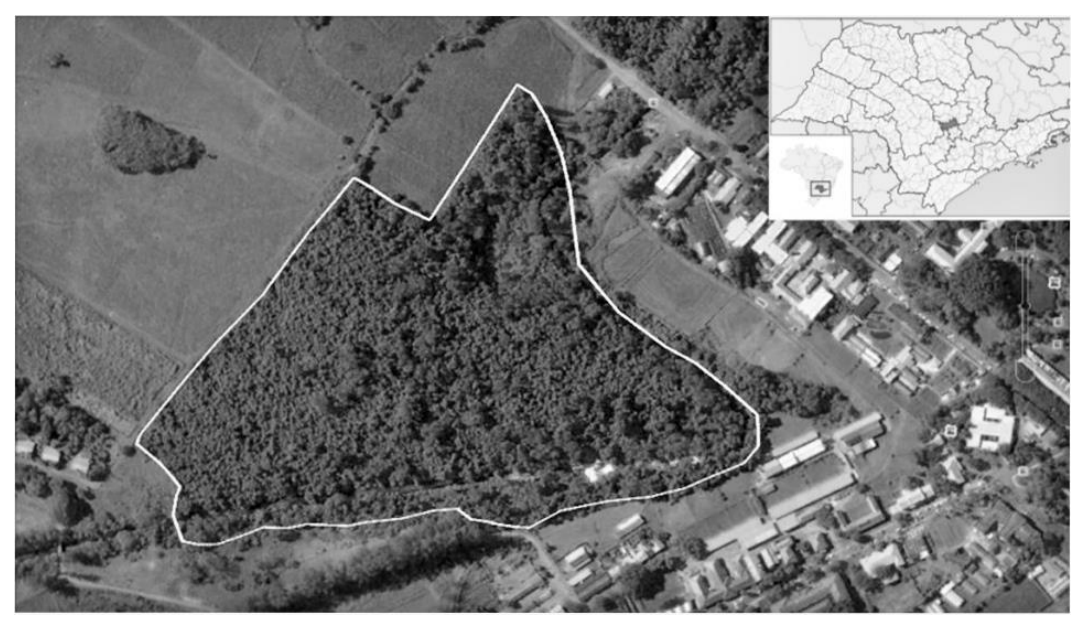

Figure 1. Semideciduous Seasonal Forest fragment - Mata da Pedreira, located within the campus of ESALQ/USP in Piracicaba, state of São Paulo, Brazil. In the figure it is possible to observe the River Piracicamirim which runs from right to left of the picture. The border of the fragment opposite to the pasture is located at the top left of the picture. Source: Photo courtesy of Tropical Forestry Laboratory (LASTROP) - ESALQ / USP, 2011.

The Mata da Pedreira presents a total area of 14 ha with a great diversity of flora and fauna. Its size and insertion in an agricultural matrix turns this fragment into a representative area of the forest remnants found in the region. The forest is next to an intensive pasture area in which the cattle is kept in pickets, local characteristic activity. Despite its importance, the fragment is quite degraded, allowing that herbs and shrubs species, as vines, grasses and lianas abundantly settled the area, suffocating the native tree species and making more difficult the natural regeneration of the area (LASTROP, 2011).

On the other hand, Silva et al. (2016) verified that the coverage of lianas does not interfere in the germination of the plants, but in the physical transposition of those, which are true barriers to the trees settlement. Many problems are found in this forest such as an intense edge effect, presence of invading species, fences inside the forest and roads. The presence of lianas in dense tangles of vines form an additional weight on the treetops hampering the penetration of solar radiation (ENGEL et al., 1998). 
Mata da Pedreira can be compared to a mosaic of entangled vines and more preserved areas (LASTROP, 2011). Moreover, there were fires in the area, being the last one in 1981 according to reports of former employees. This seems to have been the main degradation reason, reaching a great part of the existing forest and leaving some areas to bare ground with burned logs, which some were fallen while others remained standing.

The natural vegetation area is classified in the Brazilian Phytogeographic System as being a Seasonal Semideciduous Forest (IBGE, 1992). The local climate is subtropical humid, with hot and rainy summers and dry winters, equivalent to Cwa in Köppen classification (1948). The annual average air temperature is $21.4^{\circ} \mathrm{C}$ with a monthly average temperature of $24.8^{\circ} \mathrm{C}$ in the summer and $17.1^{\circ} \mathrm{C}$ in the winter. According to Sentelhas et al. (1998), the annual average rain in the region is $1,278 \mathrm{~mm}$ being $1000 \mathrm{~mm}$ from October to March and $278 \mathrm{~mm}$ from April to September, occurring hydric deficit of $213 \mathrm{~mm}$ in the dry period and an exceeding one of $234 \mathrm{~mm}$ in the rainy period.

To the evaluation of the floristic composition at the edge vegetation, three radial transect of 10 $\mathrm{m}$ wide by $50 \mathrm{~m}$ long were installed distributed in a regular order. Each transect was divided into five subplots of $10 \mathrm{~m}$ long. They were called T1 (0-10 m), T2 (10-20 m), T3 (20-30 m), T4 (30-40 m) and T5 (40-50 m). Transects were marked with one concrete pole in one of its vertices, and in the other vertices wooden poles united by a cotton string were used.

The diameters at breast height $(\mathrm{DBH})$ of the trees with more than $5 \mathrm{~cm}$ were measured and identifying plaques were put on them. They were distinguished according to species and genus by a graduate student in Systematic Botany. Depending on the difficulty in the identification, the vegetal material was collected and brought to the Herbarium at ESALQ-USP to be compared and classified. The trees distinguished in species level were classified into pioneers and non-pioneers according to its successional group. A bibliographic consultation was achieved. With the DBH data both the basal area $\left(\mathrm{m}^{2} \cdot \mathrm{ha}^{-1}\right)$ and the individual density (ind.ha $\left.{ }^{-1}\right)$ were calculated in each edge distance.

The Shannon-Wiener (1949) index was used for the evaluation of the richness and abundance of the species. This index allows the measurement of the species diversity in a certain place in a situation in which the community cannot be shown in its totality. The index was calculated according to the following equation: $\mathrm{H}^{\prime}=-\sum \mathrm{pi} * \log \mathrm{pi}$, where: $\mathrm{pi}=$ relative abundance (proportion) of species $\mathrm{i}$ in the sample and $\mathrm{pi}=\mathrm{ni} / \mathrm{N}$, where: $\mathrm{ni}=$ number of individuals of species $\mathrm{i} ; \mathrm{N}=$ number of total individuals in the sample. 


\section{RESULTS AND DISCUSSION}

In the evaluated transects, 139 individuals corresponding to 28 families, 33 genus and 36 species were sampled.

Table 1. List of species found, their successional group and distribution in different sections evaluated along the $50 \mathrm{~m}$ long transects installed in the radial direction (edge-center) in a fragment of a seasonal semideciduous forest - Mata da Pedreira, in Piracicaba, State of São Paulo, Brazil.

\begin{tabular}{|c|c|c|c|c|c|c|c|c|}
\hline \multirow{2}{*}{ Family } & \multirow{2}{*}{ Species } & \multirow{2}{*}{ SG* } & \multicolumn{6}{|c|}{ Number of trees (individuals) } \\
\hline & & & $0-10$ & $10-20$ & 20-30 & $30-40$ & $40-50$ & Total \\
\hline Fabaceae-cercidae & Bauhinia forficata & $\mathrm{P}$ & 15 & 10 & 1 & 1 & 5 & 32 \\
\hline Urticaceae & Urera baccifera & $\mathrm{P}$ & 1 & 7 & 7 & 4 & 4 & 23 \\
\hline Euphorbiaceae & Croton floribundus & $\mathrm{P}$ & - & - & 2 & 1 & 5 & 8 \\
\hline Euphorbiaceae & Croton spp. & $\mathrm{P}$ & - & 1 & 2 & 2 & 3 & 8 \\
\hline Dilleniaceae & Curatella americana & $\mathrm{P}$ & 1 & 2 & - & 1 & 3 & 7 \\
\hline Solanaceae & Solanum granuloso-leprosum & $\mathrm{P}$ & 2 & 2 & - & 1 & 1 & 6 \\
\hline Mimoisoideae & Inga uruguensis & $\mathrm{P}$ & - & - & 1 & 2 & 1 & 4 \\
\hline Meliaceae & Guarea guidonia & NP & 1 & - & - & 1 & 2 & 4 \\
\hline Malvaceae & Guazuma ulmifolia & $\mathrm{P}$ & 1 & - & - & 2 & 1 & 4 \\
\hline Malvaceae & Ceiba speciosa & NP & 1 & - & 1 & 2 & - & 4 \\
\hline Meliaceae & Trichilia casaretti & NP & - & - & 1 & - & 2 & 3 \\
\hline Fabaceae-faboideae & Lonchocarpus muehlbergianus & NP & 2 & 1 & - & - & - & 3 \\
\hline Phytolaccaceae & Gallesia integrifolia & NP & 2 & - & 1 & - & - & 3 \\
\hline Not identified & Not identified 1 & - & - & - & - & 1 & 2 & 3 \\
\hline Malvaceae & Bastardiopsis densiflora & $\mathrm{P}$ & 1 & 1 & - & - & - & 2 \\
\hline Fabaceae-mimosoideae & Senegalia polyphylla & $\mathrm{P}$ & - & 1 & - & - & 1 & 2 \\
\hline Annonaceae & Duguetia lanceolata & NP & - & - & - & 2 & - & 2 \\
\hline Rutaceae & Zanthoxylum fagara & NP & - & - & - & 2 & - & 2 \\
\hline Not identified & Not identified 2 & - & - & - & - & - & 1 & 1 \\
\hline Leguminosae-Papilionoideae & Myroxylon peruiferum & NP & 1 & - & - & - & - & 1 \\
\hline Not identified & Not identified 3 & - & - & - & - & 1 & - & 1 \\
\hline Lauraceae & Nectandra megapotamica & NP & - & - & - & 1 & - & 1 \\
\hline Rubiaceae & Coutarea hexandra & NP & - & - & - & 1 & - & 1 \\
\hline Solanaceae & Solanum ganuloso-leprosum & $\mathrm{P}$ & - & - & 1 & - & - & 1 \\
\hline Flacourtiaceae & Casearia sylvestris & $\mathrm{P}$ & 1 & - & - & - & - & 1 \\
\hline Meliaceae & Guarea sp. & - & - & - & 1 & - & - & 1 \\
\hline Bignoniaceae & Tecoma stans & $\mathrm{P}$ & - & - & 1 & - & - & 1 \\
\hline Not identified & Not identified 4 & - & 1 & - & - & - & - & 1 \\
\hline Rutaceae & Zanthoxylum riedelianum & NP & - & 1 & - & - & - & 1 \\
\hline Fabaceae & Machaerium aculeatum & $\mathrm{P}$ & - & - & 1 & - & - & 1 \\
\hline Fabaceae-mimosoideae & Piptadenia gonoacantha & $\mathrm{P}$ & 1 & - & - & - & - & 1 \\
\hline Apocynaceae & Aspidosperma subincanum & NP & - & - & 1 & - & - & 1 \\
\hline Brassicaceae & Crateva tapia & NP & - & - & - & - & 1 & 1 \\
\hline Rubiaceae & Psychotria sp. & - & - & 1 & - & - & - & 1 \\
\hline Not identified & Not identified 5 & - & - & 1 & - & - & - & 1 \\
\hline Not identified & Not identified 6 & - & - & - & 1 & - & - & 1 \\
\hline Not identified & Not identified 7 & - & - & - & 1 & - & - & 1 \\
\hline Speci & ness & - & 14 & 11 & 15 & 16 & 14 & - \\
\hline
\end{tabular}


Table 1 shows the abundance of the species found as a function of the edge distance, being organized according to the species with a greater number of individuals to a smaller one. There is also a classification of the sucessional group (pioneer and non-pioneer) to which the species belongs and the richness of the species.

The high incidence of lianas in some trees prevented the visualization of the leaves as well as the identification of around $10 \%$ of the trees. This difficulty has also been reported by Tabanez et al. (1992) in a forest situated in Planalto Paulista, where $4.7 \%$ could not be identified due to the presence of lianas. From the total of families found, seven of them $(6.4 \%)$ were not identified. From the 33 genus found, three of them (Guarea, Zanthoxylum and Croton) totalized $17.2 \%$ of the individuals sampled. As to the 36 species, three of them could not be identified (2.1\%), being that only four species $(4.3 \%)$ were identified by their popular names. From these species found, 14 were pioneers $(73.4 \%), 13$ non-pioneers $(20.8 \%)$ and the rest of the individuals was not identified $(6.4 \%)$.

The minimum richness found was of 11 species in T2 and the maximum in 16 different species in T3. The diversity of the species calculated by Shannon-Wiener index was lower in T1 and T2 (0-20 m) with H' values close to 2.0. The higher diversity was found in T3 (20-30 m) with H' value of 2.7 reducing until 2.39 in T5 $(40-50 \mathrm{~m})$. There was a predominance of pioneers' species along all the transection with greater difference between the two successional groups in the 20 first meters next to the edge (Figure 2).

The higher density of pioneers in all the transection and mainly till the $20 \mathrm{~m}$ sampled is a clear indicative of disturbance to the forest. In tropical forests, the pioneer species occur in low density, being rare in these formations. The dominance of pioneers in fragmented formations is one of the characteristics which distinguishes it from the mature mesophyll forests of the region (HUBBELL \& FOSTER, 1986). There is more probability to find pioneers in larger clearings, which correspond to 1 to $2 \%$ of the mature forest area (MARTINEZ-RAMOS, 1985). A higher representativeness (65.2\%) of pioneers was also seen in forest fragments in the interior of São Paulo State by Nascimento et al. (1998) using transects which crossed all the forest. Bernacci et al. (2006) found 65\% of pioneers in transition fragments between the Atlantic Forest in hillside and Semideciduous Mesophyll Forest as well as 39\% in a continuous forest in Morro Grande Reserve/MG. 


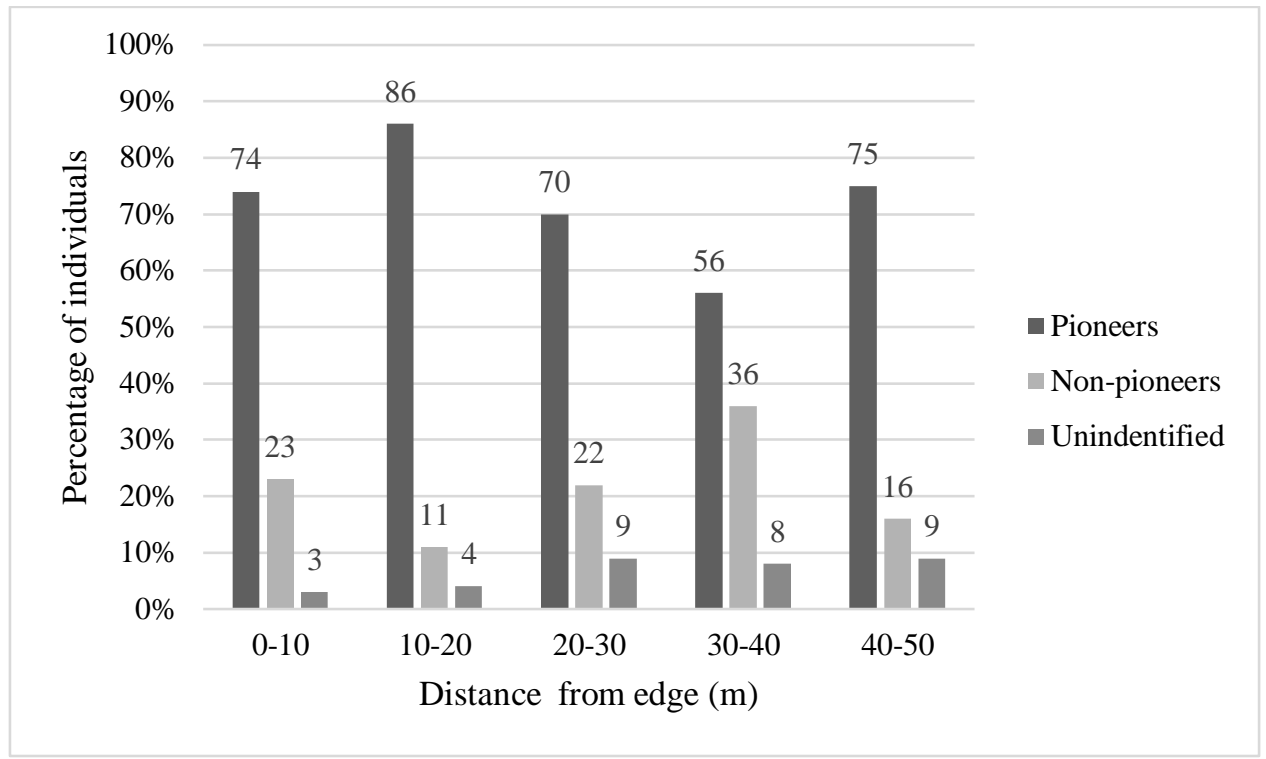

Figure 2. Percentage of pioneer species, non-pioneer and unidentified ones present in the radial edge transects up to 50 meters into the center of the semideciduous seasonal forest fragment Mata da Pedreira, in Piracicaba, State of São Paulo, Brazil.

The following families: Fabaceae (5 species), Urticaceae (1), Meliaceae (3) and Euphorbiaceae (2) represented more than half of the individuals (62.6\%). In Figure 3 we can see the four families more representative by studied section, where it is possible to see that there is a high density of individuals of the same family in the closest sections to the fragment edge.

There was a predominance of two pioneer species: Bauhinia forficata (L.) and Urera baccifera (L.) Gaudich. ex Wedd in the studied forest which summed reached almost $40 \%$ of the total of individuals sampled and represented respectively 213 ind.ha ${ }^{-1}$ e 153 ind.ha ${ }^{-1}$. The third higher density was obtained by two species of the genus Croton, with 53 ind.ha $^{-1}$ each. From that point onwards, the density decreased until 7 ind.ha ${ }^{-1}$. As to the basal area, the higher value $\left(37.7 \mathrm{~m}^{2} . \mathrm{ha}^{-1}\right)$ was obtained in $\mathrm{T} 1(0-10 \mathrm{~m})$, being that the species Bastardiopsis densiflora presented a basal area of $13.7 \mathrm{~m}^{2} . \mathrm{ha}^{-1}$ (36\%), followed by B. forficata, with $9 \mathrm{~m}^{2} \cdot \mathrm{ha}^{-1}(24 \%)$. The lower basal area was found in the section more inland in T4 (30-40 m) with a value of $10.4 \mathrm{~m}^{2} \cdot \mathrm{ha}^{-1}-$ almost a quarter of the basal area found in the fragment border. 


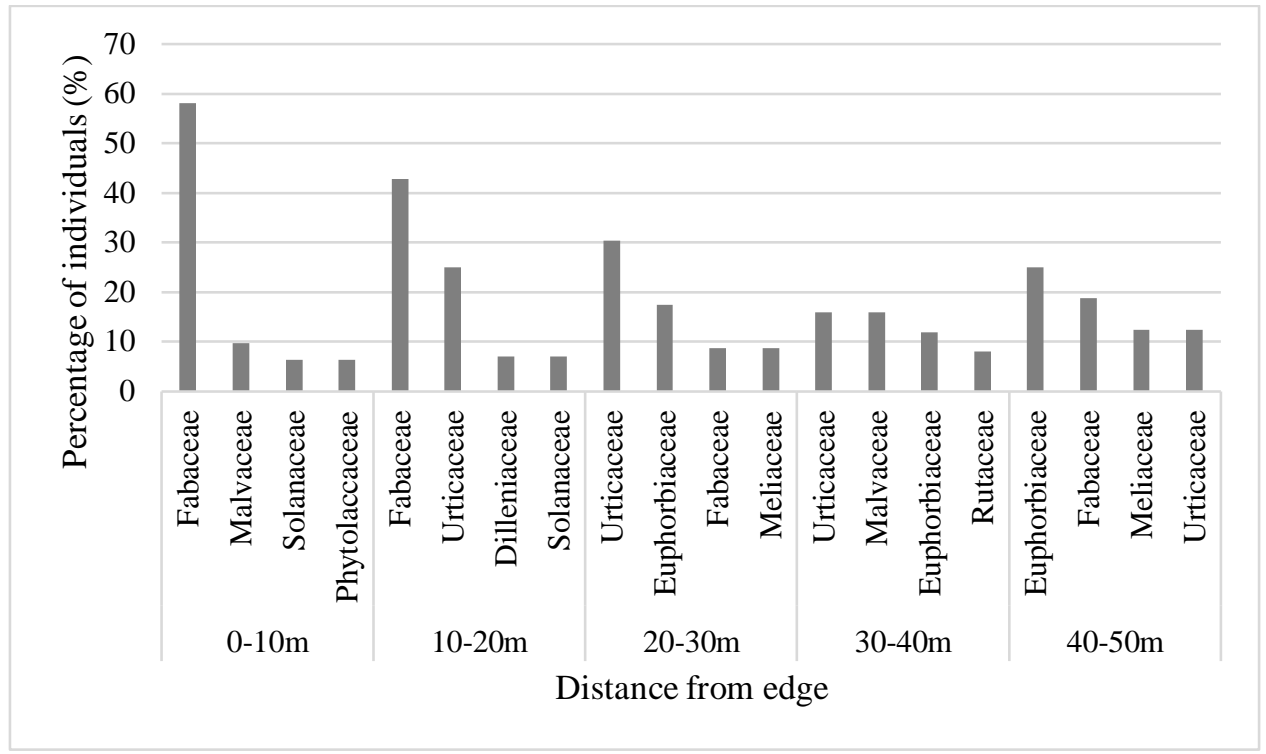

Figure 3. Percentage of individuals from the five most representative families present at transections of $50 \mathrm{~m}$ long installed in the radial direction (edge-center) in a semideciduous seasonal forest fragment of - Mata da Pedreira, in Piracicaba, State of São Paulo, Brazil.

The species B. forficata, also known as "pata-de-vaca", is peculiar of wet alluvial plains or beginning of hillsides, usually found in formations as tropical second-growth forests. It occurs in many soil types, being able to stand soaking periods (CARVALHO, 1994), which can easily occur in Mata da Pedreira. As mentioned by Alexandrino et al. (2013), the river Piracicaba and two of its affluents Piracicamirim and Monte Olimpo - pass through Esalq Campus, originating flooding areas and artificial dams. Nevertheless, these same characteristics can induce to an uncontrolled proliferation in environments with less competition, as found in this study. This species presented a higher density of individuals in the distance of 10 to $20 \mathrm{~m}$, presenting 15 and 10 individuals respectively. From this point onwards it fell to only 1 individual in T3 and T4, increasing again in T5 with 5 individuals.

The second species with a higher representativeness, U. baccifera or "urtigão", belong to the Urticaceae family. This is known by its wide use in medicinal and industrial area, in addition to some species being pioneer plants in degraded areas (KARSBURG \& BATTISTIN, 2006). There are reports in which this species is found in forests recently disturbed by fire (FRANCIS, 2004), such as Mata da Pedreira. U. baccifera was found by Rosot et al. (2007) in their study in a forest area degraded by fire. In contrast to the situation found with B. forficata, this species presented a lower density at the edge with only 1 individual in the onset of the transect, increasing to 7 individuals in T2 and T3, and decreasing again to 4 individuals in the last marks. 
The density of B. forficata and U. baccifera species in this study are comparable to the ones obtained by Nascimento et al. (1998) that observed 182 e 108 ind.ha-1 respectively. On the other hand, the distribution in the transections of those species indicates a competition between them, as usually those species do not share the same space and, in this study, they were found clustered.

The changes in the edge environment benefit plant growth, which are able to develop themselves in these new conditions, becoming each time more abundant due to their adaptability as well as changing the original floristic composition of the forest (VIANA \& PINHEIRO, 1998; NASCIMENTO et al., 1998). The identification of these species may be used as an indicative of disturbance as well as to plan protection actions and forest fragments restoration.

Melo and Durigan (2010) in their study of edge in Semideciduous Forest obtained 45 and 66 of richness in distances 0-20 m and 20-50 m from the edge, and 14 and 26 in the same distances six months after the burning in the surrounding area. The results obtained in this study are equal to the results of areas that suffered recent disturbances, like the ones presented by Leitão-Filho (1987) where, in Semideciduous Mesophyll Forest of Planalto, the Fabaceae, Meliaceae, Rutaceae, Euphorbiaceae, Lauraceae and Myrtaceae families showed a higher number of species in these formations.

\section{CONCLUSION}

This study presented an indicative of degradation, such as low richness (from 11 to 16), high density of pioneers (from $56 \%$ to $86 \%$ ) and a great abundance of two species (B. forficata with $23 \%$ and $U$. baccifera with $16.5 \%$ ) until $50 \mathrm{~m}$, confirming that probably the edge effect extends to beyond the sampled distance. The differences found in this study distinguish the flora from the studied area from those found in other forests of the same formation.

The results of the evaluation of forest fragments should be a base for the strategies which seek their protection and restoration. The change of the predominant matrix in which the fragments are inserted, through alternative uses of production, becomes an important point to diminish the edge effect and help the perpetuation of species. Moreover, the surrounding quality can be enhanced by making border plantations around the forest remnant, thus increasing its protection. The purpose of the implementation of agricultural systems with less environment impact has been discussed seeking to protect the forests, including in the redefinition of areas in permanent preservation. According to authors, the species inclusion and the formation of organic matter in the agroforestry system may be important points in the recuperation of degraded areas. 


\section{ACKNOWLEDGMENTS}

To the São Paulo Research Foundation "Fundação de Amparo à Pesquisa do Estado de São Paulo") - FAPESP for the financial support.

\section{REFERENCES}

ALEXANDRINO, E.R.; BOVO, A.A.A.; DA LUZ, D.T.A.; COSTA, J.C. da; BETINI, G.S.; FERRAZ, K.M.P.M.B.; COUTO, H.T.Z. 2013. Aves do campus "Luiz de Queiroz" (Piracicaba, SP) da Universidade de São Paulo: mais de 10 anos de observações neste ambiente antrópico. Atualidades Ornitológicas, Ivaiporã, n. 173, p. 40-52. Available at: < http://www.ao.com.br/download/AO173_40.pdf>. Access in: March 03, 2015.

BERNACCI, L.C., FRANCO, G.A.D.C., ÀRBOCZ, G.F., CATHARINO, E.L.M., DURIGAN, G.; METZGER, J.P. et al. 2006. O efeito da fragmentação florestal na composição e riqueza de árvores na região da Reserva Morro Grande (Planalto de Ibiúna, SP). Revista do Instituto Florestal, São Paulo, v. 18, p. 121-166. Available at: < http://eco.ib.usp.br/lepac/paisagem/Artigos/bernacci2006.pdf>. Access in: March 03,2015.

CARVALHO, P.E.R. 1994. Espécies florestais brasileiras: recomendações silviculturais, potencialidades e uso da madeira. Brasília, DF: Embrapa Informação Tecnológica, 639 p.

DEAN, W. 1995. A ferro e fogo: a história e a devastação da Mata Atlântica brasileira. 1 ed. São Paulo: Cia das Letras, 484 p.

ENGEL, V.L.; FONSECA, R.C.B.; OLIVEIRA, R.E. 1998. Ecologia de lianas e o manejo de fragmentos florestais. Série Técnica Ipef, Piracicaba, v. 12, n. 32, p. 43-64. Available at: < https://www.researchgate.net/profile/Vera_Lex_Engel/publication/237340325_Ecologia_de_lianas _e_o_manejo_de_fragmentos_florestais/links/545a838e0cf2c46f6643822d.pdf>. Acces in: March 10, 2015.

FRANCIS, J.K. 2004. Wildland shrubs of the United States and its Territories: thamnic descriptions. San Juan, PR: U.S. Department of Agriculture, Forest Service, International Institute of Tropical Forestry, $830 \mathrm{p}$.

HUBBELL S.P.; FOSTER R.B. 1986. Commonness and rarity in a neotropical forest: implications for tropical tree conservation. In: SOULÉ, M. E. (Ed.) Conservation Biology. Sinuar Press. Massachusetts, p. 205-231.

IBGE. 1992. Manual técnico da vegetação brasileira. Rio de Janeiro, n. 1, 92 p.

INSTITUTO FLORESTAL. 2005. Inventário Florestal da Vegetação Natural do Estado de São Paulo. São Paulo: Secretaria de Estado do Meio Ambiente/Instituto Florestal, 199 p.

KARSBURG, I.V.; BATTISTIN, A. 2006. Meiose e número cromossômico de cinco espécies da família Urticaceae do rio grande do sul. Revista de Ciências Agro-Ambientais, Alta Floresta, v. 4, n. 1, p. 47-60, Available at: < http://www.unemat.br/revistas/rcaa/docs/vol4/6_artigo_v4.pdf>. Access in: March 19, 2015.

KÖPPEN, W. 1948. Climatologia: con un estudio de los climas de la tierra. México: Fondo de Cultura Econômica, 496 p.

LABORATÓRIO DE SILVICULTURA TROPICAL - LASTROP. 2011. Restauração da mata da pedreira: desenvolvimento de métodos de manejo para a ampliação da conservação da biodiversidade e da geração de serviços ambientais em fragmentos florestais degradados. Available at: < http://esalqlastrop.com.br/capa.asp?j=25>. Access in: March 19, 2015. 
LEITÃO-FILHO H.F. 1987. Considerações sobre a florística de florestas tropicais e sub- tropicais do Brasil, Série Técnica Ipef, Piracicaba, v. 35, p. 41-46,

LIMA-RIBEIRO, M.S. 2008. Efeitos de borda sobre a vegetação e estruturação populacional em fragmentos de Cerradão no Sudoeste Goiano. Acta Botanica Brasilica, Belo Horizonte, v. 22, p. 535-545, Available at: < http://www.scielo.br/scielo.php?pid=S010233062008000200020\&script=sci_arttext>. Access in March 01, 2015.

MARTINEZ-RAMOS M. 1985. Claros, ciclo vitales de lós arboles tropicales y regeneración natural de las selvas altas perennifoliadas. In: GOMEZ-POMPA, A. (Ed.) Investigaciones sobre la regeneración de selvas altas em Veracruz, Mexico. Editorial Alhambra Mexicana, México, v. 2, p.191-239.

MELO, A.C.G.; DURIGAN, G. 2010. Impacto do fogo e dinâmica da regeneração da comunidade vegetal em borda de Floresta Estacional Semidecidual (Gália, SP, Brasil). Revista Brasileira de Botânica, São Paulo, v. 33, n. 1, p. 37-50, Available at: < http://www.scielo.br/scielo.php?script=sci_arttext\&pid=S0100-84042010000100005>. Access in March 16, 2015.

NASCIMENTO, H.E.M.; DIAS, A. DA S.; TABANEZ, A.A.J.; VIANA, V.M. 1998. Estrutura e dinâmica de populações arbóreas de um fragmento de floresta estacional semidecidual na região de Piracicaba, SP. Revista Brasileira de Biologia, São Carlos, v. 59, n. 2, p. 329-342.

NASCIMENTO, H.E.M.; LAURANCE, W.F. 2006. Efeitos de área e de borda sobre a estrutura florestal em fragmentos de floresta de terra-firme após 13-17 anos de isolamento. Revista Acta Amazônica, Manaus, v. 36, n. 2, p. 183-192, Available at: < http://www.scielo.br/scielo.php?script=sci_arttext\&pid=S0044-59672006000200008>. Access in March 15, 2015.

RIBEIRO, M.C.; METZGER, J.P.; MARTENSEN, A.C.; PONZONI, F.J.; HIROTA, M.M. 2009. The brazilian Atlantic forest: how much is left, and how is the remaining forest distributed? Implications for conservation. Biological Conservation, Brasil, v. 142, n. 6, p. 1141-1153,

RODRIGUES, E. 1998. Efeito de Borda em Fragmentos de Floresta. Cadernos de Biodiversidade, Londrina, v. 1, p. 1-5, Available at: < http://www.iap.pr.gov.br/arquivos/File/Publicacoes/ Cadernos\%20da\%20Biodiversidade/Cadesrnos_da_Biodiversidade_V1n2/CADERNOS_2_VERS. pdf>. Access in: March 07, 2015.

ROSOT, N.C.; DUGLOSZ, F.L.; ROSOT, M.A.D.; RURASZ, G.; OLIVEIRA, Y.M.M. de. 2007. Ações de recuperação em área degradada por fogo em Floresta Ombrófila Mista: resultados parciais. Pesquisa Florestal Brasileira, Colombo, v. 55, p. 23-30,

SENTELHAS, P.C.; MARIN, F.R.; ANGELOCCI, A.R.; VILLA NOVA, N.A.; BARBIERE, V.1998. Análise dos dados climáticos e do balanço hídrico climatológico de Piracicaba (1917-1997). Piracicaba: DFM/ESALQ/USP, $81 \mathrm{p}$.

SHANNON, C.E.; WEAVER, W. 1949. The Mathematical Theory of Communication. Urbana: University of Illinois Press. 117p.

SIFESP - Sistema de Informações Florestais do Estado de São Paulo. Available at: < http://www.iflorestal.sp.gov.br/imagindex/mapainventario.pdf >. Access in February 28, 2015.

SILVA, M.A.; RODRIGUES, M.M.; RIGHI, C.A. 2016. Cobertura de lianas no dossel florestal e seus efeitos sobre a regeneração de espécies arbóreas. Revista do Instituto Florestal, São Paulo, v. 28 n. 1. p. 37-47,

TABANEZ A.A.J.; VIANA V.M.; DIAS A.S. 1992. Consequências da fragmentação e do efeito de borda sobre a estrutura, diversidade e sustentabilidade, de um fragmento de floresta de planalto de Piracicaba, SP. Revista Brasileira de Biologia, São Carlos, v. 57, p. 47-60, 
VIANA, V.M., 1995. Conservação da biodiversidade de fragmentos florestais em paisagens tropicais intensamente cultivadas. In: Abordagens interdisciplinares para a conservação da biodiversidade biológica e dinâmica do uso da terra, Belo Horizonte, p. 135-154.

VIANA, V.M.; PINHEIRO, L.V. 1998. Conservação da biodiversidade em fragmentos florestais. Série Técnica IPEF, Piracicaba v. 12, n. 32, p. 25-42, Available at: < http://www.ipef.br/publicacoes/stecnica/ nr32/cap03.pdf>. Access in March 10, 2015.

ZORZETTO, R. 2010. O Verde clandestino. Revista Fapesp, São Paulo, v. 170, p. 50-53, Available at: < http://revistapesquisa.fapesp.br/wp-content/uploads/2012/08/050-053-170.pdf?5b33bc>. Access in March 09, 2015. 